\title{
GC-MS and Antioxidant Capacity Analysis in Propanol Extract of Carthamus Tinctorious L
}

\author{
Sri Indriati ${ }^{1, a, *}$, Muhammad Yusuf ${ }^{1, b}$, Riskayanti ${ }^{1}$, Nur Amaliah $^{1}$, Mahyati Latief $^{1, \mathrm{c}}$, Rahmiah Sjafruddin $^{1, \mathrm{~d}}$, \\ Nur Fitriani $\mathbf{U A}^{2, \mathrm{e}}$ \\ ${ }^{1}$ Department of Chemical Engineering, Politeknik Negeri Ujung Pandang, Makassar City, 90245, Indonesia. \\ ${ }^{2}$ Department of Agroindustry, Politeknik Pertanian Negeri Pangkep, Pangkep Regency, 90761, Indonesia. \\ a, ${ }^{*}$ indriati.sri59@gmail.com (Corresponding Author) \\ byusufitri@poliupg.ac.id \\ ${ }^{\mathrm{c}}$ mahyatikimia@poliupg.ac.id \\ drahmiah.sjafruddin@gmail.com \\ e nurfitriani.attahmid@polipangkep.ac.id
}

\begin{abstract}
Safflower, were extracted using propanol solvent at different time intervals: 10,20 , and 30 min at a constant temperature of $40^{\circ} \mathrm{C}$. The extracts were analyzed by GC/MS technique. The major compounds identified were tetrapentacontane, tetracontane, triacontanol, gamma sitosterol, myristic acid, linoleic acid, stearic acid, palmitic acid, oleic acid, and lauric acid. However, some levels of palmidrol, beta-amyrin, cubenol, and tocopherol were also found in safflower extracts. Most of the volatile compounds were detected between 10-30 min time of extraction. The 30 min time of extraction also showed the maximum content of polyphenols and antioxidants in safflower extracts. Thus, 30 min was suggested as the most suitable time for maximum extraction of bioactive volatiles, antioxidants, and polyphenols from Safflower using propanol solvent.
\end{abstract}

Keywords: Antioxidants; Gas chromatography-mass spectrometry; Polyphenols; Propanol; Safflower.

\section{Introduction}

Safflower (Carthamus tinctorius $L$ ) is known by the Bugis-Makassar community as 'Kasumba turate' or 'Kasumba ogi'. Safflower is used as a dye on foodstuffs and traditional medicines empirically used by the people of South Sulawesi to treat measles. Natural antioxidants can be found in plants that are high in these compounds. Safflower has long been used as a source of edible fat, food colorants, and Chinese medicine. There are some reports on antioxidative compounds derived from Safflower that describe their activity in scavenging free radical species such as superoxide anion $\left(\mathrm{O}_{2}\right)$ [1] and a,a-diphenyl-h-picrylhydrazyl (DPPH) radical [2], [3], indicating the importance of safflower as antioxidant source material. Bioactive compounds of yellow and red Safflower are flavonoids, kaempferol, glycosides, serotonin, and sterols. Phenolic compounds, flavonoids, and carotenoids are secondary metabolites with antioxidant, antibacterial, antiviral, anti-inflammatory, anti-allergy, and anti-cancer activity [4].

Some studies explain that antioxidant compounds can inhibit free radicals in the body, which are obtained endogenously (superoxide dismutase enzymes) and exogenous through food or supplements [5], [6]. Some antioxidant compounds can be found in plants derived from polyphenols, vitamin $\mathrm{C}$, vitamin $\mathrm{E}, \beta$-carotene, and flavonoids [6], [7]. Kasumba turate potential to be developed as a functional food, as it contains polyphenols and antioxidants that are useful to ward off free scavenging activity. Research [8], examined the potential of Safflower is subjected to natural pollination by Apis mellifera honeybees in Tacheng City, China. Safflower is extracted by maceration using ethanol solvent $95 \%$ for $24 \mathrm{~h}$, obtained 14 polyphenol components such as protocatechuic acid, gallic acid, 
caffeic acid, and ferulic acid. The flavonoids produced are about $83.4 \%$, only about $43.4 \%$ are classified as having a high antioxidant activity (DPPH $\mathrm{IC}_{50}<50$ ). Then, research on Safflower using a combination of ultrasonic-assisted extraction methods and direct solvents in ethanol solvents, showed the maximum potential of Safflower as an antioxidant and antibacterial with an extraction time of $45 \mathrm{~min}$ and a temperature of $37^{\circ} \mathrm{C}$ [9]. In addition, the potential of safflower type yellow A originating from Terra e Vita, Italy. Results showed that this plant is classified as a high antioxidant because it contains polyphenols $3.5(\mathrm{GAE}) / 100 \mathrm{~g}$ and flavonoids 330 (CE)/100 [10].

Antioxidants from plants are obtained through extraction with solvents based on the level of solubility of these compounds. Alcoholic compounds such as ethanol, methanol, and propanol are solvents for extracting all groups of flavonoids. The most commonly used extraction method is maceration, immersing the sample using a solvent with or without stirring. Maceration is generally slow, requires a lot of solvents, and produces low yields. Sufficiently high temperature is used to increase the extracted compounds' solubility to accelerate the antioxidant oxidation process. Ultrasonicassisted extraction (UAE) is one of the ultrasonicassisted extraction methods. Ultrasonic waves have a sound frequency above human hearing ( $\geq 20 \mathrm{kHz}$ ) [11], [12]. The process of extracting organic compounds in plants and grains using organic solvents can take place more quickly with the help of ultrasonics. Ultrasonic vibrations break down the cell wall of the material, and the contents come out easily [13], [14]. The main advantages of ultrasonic-assisted extraction over conventional extraction using maceration are greater efficiency and shorter operating time.

Identify the bioactive compounds of Safflower to gain a better understanding of the physiological and pharmacological properties of Safflower. The effect of extraction time with ultrasonic-assisted extraction methods on the bioactive compounds of Safflower has not yet been reported, to the best of the authors' knowledge. In general, gas chromatography and mass spectrometry (GC-MS) are used to analyze bioactive compounds. This study aimed to comprehensively investigate the effect of extraction time with ultrasonicassisted extraction methods using propanol solvents on safflower bioactive compounds, antioxidants activity, and polyphenolic content.

\section{Research Methodology}

\subsection{Materials}

Dried Safflower (Fig. 1) were purchased from the local market and stored at room temperature until use. Gallic acid monohydrate, sodium carbonate, quercetin, Folin Ciocalteau's phenol reagent, potassium acetate, and 1,1-diphenyl-2-picrylhydrazyl-hydrate (DPPH) were all purchased from Sigma-Aldrich (Singapore). Propanol were purchased from Merck (Singapore). Most of the chemicals are used analytical grade and were used and without purification.

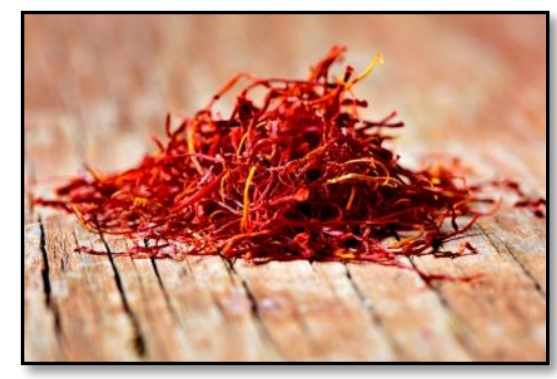

Figure 1. Safflower (Carthamus tinctorius L)

\subsection{Extraction of Safflower}

In the early extraction stages, $2 \mathrm{~g}$ of dried Safflower were extracted in $20 \mathrm{ml}$ propanol solvent $(1: 20)$ at a constant temperature of $40^{\circ} \mathrm{C}$ for 10,20 , and $30 \mathrm{~min}$ using ultrasonic-assisted extraction methods (Elma Easy Ultrasonic $10 \mathrm{H}$ ) with a frequency of $37 \mathrm{kHz}$. The extracts were concentrated in a rotary evaporator under reduced pressure (Buchi Rotavapor R-100).

\subsection{Conditions for the instrument and chromatography}

The filtrate was pipetted using PVDF Syringe Filter (SFPVDF013022NA) pore size $0.22 \mu \mathrm{m}$, diameter 13 mm (membrane solutions), and collected in vial glass. GC-MS Shimadzu QP-2010 Plus was used to analyze the extracts. $\mathrm{GC}$ temperature was set at $100^{\circ} \mathrm{C}$ for $2 \mathrm{~min}$ and then increased to $240^{\circ} \mathrm{C}$ for $18 \mathrm{~min}$. Capillary 
column RTX-5 (30 mm x $0.25 \mathrm{~mm} \times 0.25 \mu \mathrm{m})$, Split ratio $40: 1$, heating rate $10^{\circ} \mathrm{C} \mathrm{min}^{-1}$, up to $300^{\circ} \mathrm{C}$, maintained for 5 min with a total analysis time of 25 min. Helium was used as a carrier gas flowing at a constant $1.0 \mathrm{ml} / \mathrm{min}$; pre-column pressure was $80 \mathrm{kPa}$, Ionization voltages $70 \mathrm{eV}$.

\subsection{Free Radical Scavenging activity of Safflower}

Method of [6] with some modifications used for analysis antioxidant activity of Safflower. The stock solution of propanol extracts were diluted 1:10 (v/v) with methanol to produce sample solutions, then diluted with a concentration of $300,350,400,450 \mathrm{ppm}$. Aliquots $4 \mathrm{ml}$ of different concentrations of the safflower extract in methanol $(300-450 \mu \mathrm{L} / \mathrm{mL})$ were mixed with $1 \mathrm{~mL}$ of $1 \mathrm{mM}$ DPPH solution; for $30 \mathrm{~min}$, the thoroughly mixed solution was left at room temperature and in the dark. A Shimadzu UV Mini 1240 visible spectrometer was used to measure the mixture's absorbance at $515 \mathrm{~nm}$. The inhibition activity of the samples was calculated according to Eq. (1):

Inhibition (\%) $=\left[\frac{A_{\text {control }}-A_{\text {Sample }}}{A_{\text {control }}}\right] \times 100$

\subsection{Determination of phenolic content of Safflower}

Phenolic content of propanol extract safflower was determined using the Folin-Ciocalteu colorimetric method [15] and expressed as mg gallic acid equivalents (GAE) per $100 \mathrm{~g}$ dry weight (mg GAE/100 $\mathrm{g} \mathrm{dw}$ ). Safflower extract $(1 \mathrm{ml})$ was mixed with Folin-Ciocalteu reagents $(2 \mathrm{ml}), \mathrm{Na}_{2} \mathrm{CO}_{3}(20 \mathrm{ml})$, and added aquades to the limit mark on the volumetric flask $50 \mathrm{ml}$. The mixture was shaken for $2 \mathrm{~min}$, and $2 \mathrm{ml}$ of the saturated sodium carbonate and kept in the dark for $60 \mathrm{~min}$ at room temperature $\left(28-30^{\circ} \mathrm{C}\right)$. A spectrophotometer measures sample uptake with a wavelength of $740 \mathrm{~nm}$.

\section{Results and Discussion}

\subsection{Identifying and analyzing major components}

GC-MS chromatograms of propanol extract of 10 , 20, and $30 \mathrm{~min}$ different time extraction. Safflower samples for different periods of extraction are given in Figure 2. Figure 2 shows that peak samples are identified components totally in 10,20 , and $30 \mathrm{~min}$ time of extraction, about 145, 179, and 174 compounds in sequence identified from propanol extract in Safflower. The number of volatile safflower sample constituents as described by the peak varies to a certain extent accordingly due to varying processing and extraction time. Different compounds were identified and characterized by comparing the mass spectra of the constituents to the NIST 2.7 and Willey 8 libraries. Table 1 shows the relative percentages of some major compounds present in almost all of the samples. The representative compound is Tetrapentacontane which accounts for $28.38,27.45$, and $30.79 \%$. They were identified as myristic acid, gamma sitosterol, palmitic acid, lauric acid, stearic acid, oleic acid, linoleic acid, phenols, ascorbic acid, hexatriacontane, tetracontane, tetracosane, triacontanol, and tocopherol were more abundantly present in the safflower extract. However, there are some compounds that are only found at different extraction time treatments, such as palmidrol and Santolina triene (10 min), cubenol and norolean-12ene (20 $\mathrm{min})$, and beta.-amyrin was identified at the extraction time of $30 \mathrm{~min}$. As the extraction duration is increased, the relative percentage of most physiologically relevant volatile chemicals decreases. As seen in Table 1, most of the chemicals found were beneficial to health and physiologically relevant.

\subsection{Total phenolic content of Safflower in different extraction time}

The effect of extraction time on the polyphenolic content of safflower extracts is depicted in Table 2. The content of polyphenols in tea is one of the parameters in the quality of Safflower. This is because polyphenols are one of the chemical compounds that have an essential role in maintaining health. Phenol or polyphenols are compounds with hydroxyl groups $(\mathrm{OH})$ that are bound to aromatic rings. Testing the levels of these polyphenols using the reagent Follin ciocalteu and sodium carbonate will change the color of the extract to blue. This concentration of blue color will be measured and compared to gallic acid as a reference solution for calculating polyphenol levels contained in the extract. Total phenolics are presented in Table 2 and expressed as $\mathrm{mg}$ of gallic acid equivalents/100 $\mathrm{g}$ FW. Total 
phenolics ranged from 11.89 to $96.64 \mathrm{GAE} / \mathrm{g}$. The results revealed that the time of extraction $30 \mathrm{~min}$ in Safflower has a high polyphenols $96.64 \mathrm{GAE} / \mathrm{g}$. As a result, the most significant amount of total phenols was

detected

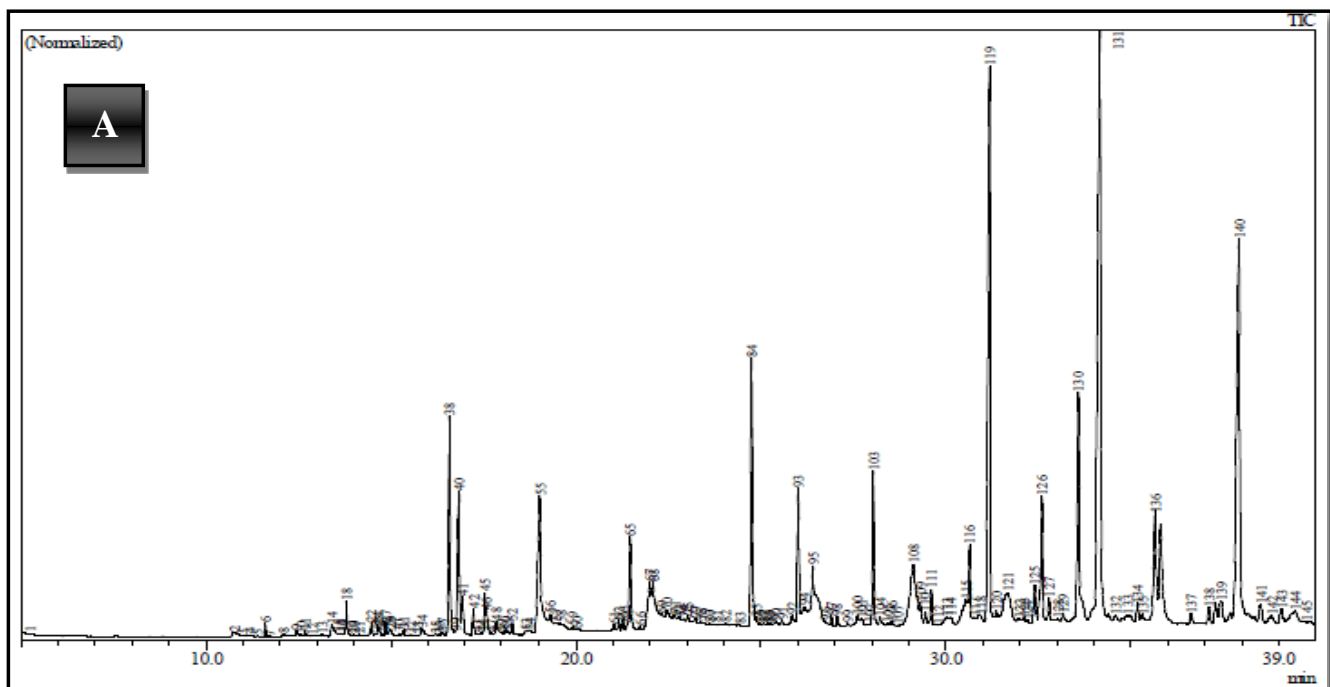

B
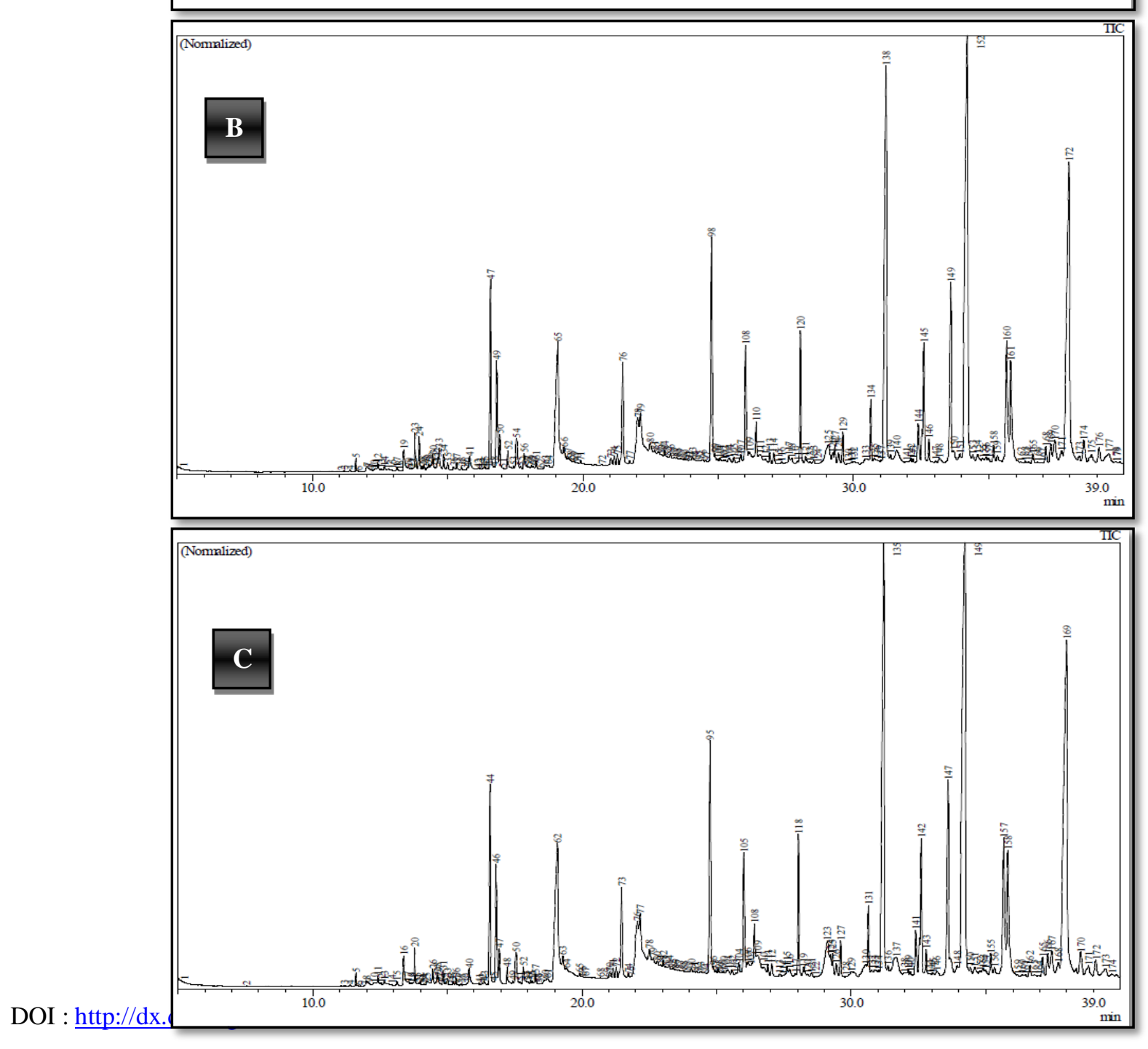

after $30 \mathrm{~min}$ of extraction, implying that this is the most efficient extraction duration for full phenolic component release in Safflower.

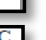


Figure 2. GC-MS chromatograph propanol extract of Safflower. (A) extraction time 10 min; (B) extraction time 20 min; (C) extraction time $30 \mathrm{~min}$.

Table 1. Relative percentages of some major compounds present in Safflower with different time extraction

\begin{tabular}{|c|c|c|c|c|c|}
\hline \multirow{2}{*}{ Bioactive compounds } & \multicolumn{3}{|c|}{ Area $(\%)$} & \multirow{2}{*}{ Bioactivity } & \multirow{2}{*}{ Reference } \\
\hline & $10 \mathrm{~min}$ & $20 \mathrm{~min}$ & $30 \mathrm{~min}$ & & \\
\hline Myristic acid & 0.17 & 1.06 & 0.68 & $\begin{array}{l}\text { Antioxidant, nematicidal, anti-carcinogenic, } \\
\text { antibacterial activity }\end{array}$ & {$[12]$} \\
\hline Palmitic acid & 0.24 & 0.61 & 1.94 & $\begin{array}{l}\text { Antioxidant, anti-carcinogenic antibacterial } \\
\text { activity, nematicide }\end{array}$ & {$[12]$} \\
\hline Stearic acid & 1.12 & 1.43 & 1.32 & Antibacterial activity & [12] \\
\hline Oleic acid & 0.19 & 0.19 & 0.36 & Anti-tumor, anti-cancer agents, and antioxidant & [12] \\
\hline Linoleic acid & 3.34 & 4.25 & 4.61 & $\begin{array}{l}\text { Anti-obesity effects, hypoglycaemic, Alzheimer's } \\
\text { dementia }\end{array}$ & {$[17]$} \\
\hline Phenolics & 0.22 & 0.08 & 0.04 & Antioxidant & [6] \\
\hline Gamma sitosterol & 1.64 & 0.04 & 0.56 & $\begin{array}{l}\text { Anti-fungi, antibacterial activity, anti- } \\
\text { inflammatory }\end{array}$ & {$[12]$} \\
\hline Tetracontane & 2.4 & 11.22 & 10.51 & $\begin{array}{l}\text { Anti-tumor activities, antidiabetic and } \\
\text { antibacterial activity }\end{array}$ & {$[18]$} \\
\hline Palmidrol & 0.01 & - & - & Antioxidative & [19] \\
\hline Hexatriacontane & 6.30 & 12.05 & 8.92 & Blood glucose lowering potency & [20] \\
\hline Santolina triene & 0.03 & - & - & Antibacterial activity & [21] \\
\hline Lauric acid & 0.31 & 0.39 & 1.1 & Antidiabetic and antioxidant activities & {$[22]$} \\
\hline Ascorbic acid & 3.89 & 4.35 & 4.35 & Antioxidant & [23] \\
\hline Phytol & 0.08 & 1.71 & 1.34 & $\begin{array}{l}\text { Precursor of synthetic vitamin E and vitamin K } \\
\text { was cytotoxic to breast cancer cell lines. (MCF7) }\end{array}$ & [18] \\
\hline Dotriacontane & 2.85 & 0.12 & 0.51 & Antimicrobial agent & {$[24]$} \\
\hline Beta.-amyrin & - & - & 1.58 & $\begin{array}{l}\text { Anti-inflammatory, anticonvulsant, } \\
\text { antidepressive, analgesic, antipancreatitic, } \\
\text { anticholytic, antihyperglycemic, gastroprotective, } \\
\text { hepatoprotective, and hypolipidemic effects }\end{array}$ & {$[25]$} \\
\hline Tetracosane & 10.06 & 0.31 & 0.39 & $\begin{array}{l}\text { Anti-cancer activity against MDA-MB-231, HT- } \\
2918, \text { AGS, and NIH } 3 \text { T3 cell lines }\end{array}$ & {$[26][18][27]$} \\
\hline Norolean-12-Ene & - & 1.10 & - & Potential for cytotoxic activity against tumor & [28] \\
\hline Triacontanol & 1.66 & 5.78 & 5.63 & anti-tumor activity. & [29] \\
\hline Tetrapentacontane & 28.38 & 27.45 & 30.79 & $\begin{array}{l}\text { Hydroxylation of liver enzymes during phase I } \\
\text { metabolism, hair growth promoter, uric acid } \\
\text { production, and arachidonic acid inhibitor in the } \\
\text { human body are therapeutic and pharmaceutical } \\
\text { benefits. }\end{array}$ & [30] \\
\hline Cubenol & - & 0.14 & - & Antimicrobial activity & [31] \\
\hline Tocopherol & 0.38 & 0.56 & 0.67 & $\begin{array}{l}\text { Alzheimer's and cardiovascular disease, anti- } \\
\text { aging, antioxidant properties }\end{array}$ & [32] \\
\hline
\end{tabular}

The decrease in total phenolic content could be due to changes in phenolic compounds' molecular structure, which could reduce extractability due to the degree of polymerization [16].

\subsection{Free Radical Scavenging activity of Safflower (DPPH assay)}

Analysis of the antioxidant activity of safflower extract using radical DPPH (2,2 diphenyl-1-pikrilhydrazil). Antioxidant compounds will react with DPPH radicals through the hydrogen atom donation mechanism and cause color decay. DPPH from purple to yellow is measured at a wavelength of $517 \mathrm{~nm}$. The parameter of 
this DPPH method is the inhibition concentration value of $50 \%\left(\mathrm{IC}_{50}\right)$ or a concentration that can reduce free radical activity by $50 \%$. Compounds have very strong antioxidant activity if $\mathrm{IC}_{50}$ values are less than $50 \mathrm{ppm}$, strong $\mathrm{IC}_{50}$ between $50-100 \mathrm{ppm}$, medium if the $\mathrm{IC}_{50}$ value is $101-150 \mathrm{ppm}$, and weak if the $\mathrm{IC}_{50}$ value is between 150-200 ppm [33]. Safflower extract using propanol solvents with various extraction times is classified as a weak antioxidant activity with a range of 1577.33 to 366.79 . It is well known that plant extracts containing polyphenolic components have antioxidant activity because of their ability to donate hydrogen atoms or electrons and capture free radicals [34]. Free radicals are well-known to play a role in biological damage. In summary, the antioxidant reduces DPPH reduction capacity by lowering its absorbance at $517 \mathrm{~nm}$. The extent of the reaction is determined by the antioxidant's hydrogen-donating ability [16].

Table 2. Effects of extraction time on total phenolic content and antioxidant activity of safflower extracts

\begin{tabular}{|c|c|c|c|}
\hline \multirow{2}{*}{ Time (min) } & \multicolumn{2}{|c|}{ Propanol solvents } & \multirow{2}{*}{ Antioxidant properties } \\
\cline { 2 - 3 } & $\begin{array}{c}\text { Total } \\
\text { Phenolic } \\
\text { Content } \\
(\mathrm{GAE} / \mathrm{g})\end{array}$ & $\begin{array}{c}\mathrm{IC}_{50} \\
(\mu \mathrm{g} / \mathrm{ml})\end{array}$ & \\
\hline 10 & 49.01 & 181.25 & Weak \\
\hline 20 & 11.89 & 366.79 & no activity \\
\hline 30 & 96.64 & 157.33 & Weak \\
\hline $\begin{array}{c}\text { Quercetin } \\
\text { (control) }\end{array}$ & 121.38 & 7.26 & Very strong \\
\hline
\end{tabular}

\section{Conclusion}

This study confirms the presence of various healthbeneficial compounds using GC-MS. Safflower extract using propanol solvents was found to be richer in myristic acid, lauric acid, palmitic acid, linoleic acid, stearic acid, and oleic acid, as well as the dominant Tetrapentacontane content of this plant, serving as an inhibitor in the human body, are some of the therapeutic and anti-cancer activity. The antioxidant and phenolic content of Safflower was found to be higher at $30 \mathrm{~min}$ of extraction time. It was concluded that the extraction time of $30 \mathrm{~min}$ is best suited for maximum retention of bioactive compounds in Safflower.

\section{Acknowledgment}

The authors are grateful to Politeknik Negeri Ujung Pandang for supporting this research through BOPTN funding by research scheme in 2021 .

\section{References}

[1] T. Kanehira et al., "A novel and potent biological antioxidant, Kinobeon A, from cell culture of safflower," Life Sci., Vol. 74, No. 1, pp. 87-97, 2003, doi: 10.1016/j.lfs.2003.06.033.

[2] Hui Li Zhang, A. Nagatsu, and J. Sakakibara, "Novel antioxidants from safflower (Carthamus tinctorius L.) oil cake," Chemical and Pharmaceutical Bulletin, Vol. 44, No. 4. pp. 874-876, 1996, doi: 10.1248/cpb.44.874.

[3] H. L. Zhang, A. Nagatsu, T. Watanabe, J. Sakakibara, and H. Okuyama, "Antioxidative compounds isolated from safflower (Carthamus tinctorius L.) oil cake," Chem. Pharm. Bull., Vol. 45, No. 12, pp. 1910-1914, 1997, doi: 10.1248/cpb.45.1910.

[4] Utami Yuri Pratiwi, Aliyah and Rahmawati Syukur, "Uji Efek Imunostimulan Kombinasi Ekstrak Mahkota Bunga Kasumba Turate (Carthamus tinctorius L) dan Ekstrak Umbi Bawang Dayak (Eleutherine palmifolia) pada mencit (Mus musculus)", (Immunostimulant Effect Test of Combination of Kasumba Turate (Carthamus tinctorius L.) Flower Crown Extract and Dayak Onion Tuber Extract (Eleutherine palmifolia) on mice (Mus musculus), JST Kesehat., Vol. 6, No. 2, pp. 179-184, 2016.

[5] J. L. Mau, H. C. Lin, and S. F. Song, "Antioxidant properties of several specialty mushrooms," Food Res. Int., Vol. 35, Issue: 6, 2002, doi: 10.1016/S0963-9969(01)00150-8.

[6] U. A. Fitriani Nur, M. Yusuf, Pirman, Syahriati, and S. Rahmiah, "Physicochemical, antioxidant and sensory properties of chocolate spread fortified with jackfruit (Artocarpus heterophyllus) flour," Food Res., Vol. 4, No. 6, pp. 2147-2155, 2020, doi: 10.26656/fr.2017.4(6).262.

[7] U. Nur Fitriani, M. Yusuf, and F. S. Ilyas, "Spray Drying of Rosella (Hibiscus sabdariffa L.) Powder: Effect of Shelf Life on Physicochemical Properties and Cyanidin 3-O-glucoside," IOP Conf. Ser. Earth Environ. Sci., Vol. 755, No. 1, pp. 1-7, 2021, doi: 10.1088/1755-1315/755/1/012002.

[8] L. P. Sun, F. F. Shi, W. W. Zhang, Z. H. Zhang, and K. Wang, "Antioxidant and anti-inflammatory activities of safflower (Carthamus tinctorius L.) honey extract," Foods, Vol. 9, No. 1039, pp. 1-16, 2020, doi: 10.3390/foods9081039.

[9] M. Esmaeelian, M. Jahani, J. Feizy, and S. Einafshar, "Effects of Ultrasound-Assisted and Direct Solvent Extraction Methods on the Antioxidant and Antibacterial Properties of Saffron (Crocus sativus L.) Corm Extract," Food Anal. Methods, Vol. 14, No. 1, pp. 1-14, 2021, doi: 10.1007/s12161-020-01855-8.

[10] T. Bacchetti, C. Morresi, L. Bellachioma, and G. Ferretti, "Antioxidant and pro-oxidant properties of Carthamus tinctorius, hydroxy safflor yellow A, and safflor yellow A," Antioxidants, Vol. 9, No. 2, pp. 1-10, 2020, doi: 10.3390/antiox9020119.

[11] J. Deng et al., "Comparative evaluation of maceration and ultrasonic-assisted extraction of phenolic compounds from fresh olives," Ultrason. Sonochem., Vol. 37, pp. 328-334, 2017, doi: 10.1016/j.ultsonch.2017.01.023. 
[12] M. Yusuf, N. F. U. Atthamid, S. Indriati, R. Saleh, M. Latief, and A. Rifai, "Optimization ultrasonic assisted extraction (UAE) of bioactive compound and antibacterial potential from sea urchin (diadema setosum)," Curr. Res. Nutr. Food Sci., Vol. 8, No. 2, pp. 556-569, 2020, doi: 10.12944/CRNFSJ.8.2.22.

[13] A. Altemimi, R. Choudhary, D. G. Watson, and D. A. Lightfoot, "Effects of ultrasonic treatments on the polyphenol and antioxidant content of spinach extracts," Ultrason. Sonochem., Vol. 24, pp. 247-255, 2015, doi: 10.1016/j.ultsonch.2014.10.023.

[14] S. U. Kadam, B. K. Tiwari, and C. P. O'Donnell, "Application of novel extraction technologies for bioactives from marine algae," Journal of Agricultural and Food Chemistry. Vol. 61, No. 20, pp. 4667-75 2013, doi: 10.1021/jf400819p.

[15] M. Yusuf, Pirman, U. A. Nur Fitriani, I. Amri, and A. I. Juwita, "Identifications of Polyphenols and $\alpha$-Amylase Inhibitory Activity of Multi herbal Formulation: Cocoa Beans (Theobroma cocoa), Buni (Antidesma bunius L. Spreng) and Cinnamons (Cinnamomum cassia)," in Journal of Physics: Conference Series, 2021, Vol. 1783, No. 1, pp. 1-9, doi: 10.1088/1742-6596/1783/1/012004.

[16] M. Ahmad, W. N. Baba, A. Gani, T. A. Wani, A. Gani, and F. A. Masoodi, "Effect of extraction time on antioxidants and bioactive volatile components of green tea (Camellia sinensis), using GC/MS," Cogent Food Agric., Vol. 1, No. 1, pp. 1-11, 2015, doi: 10.1080/23311932.2015.1106387.

[17] C. E. Ramsden et al., "Lowering dietary linoleic acid reduces bioactive oxidized linoleic acid metabolites in humans," Prostaglandins, Leukot. Essent. Fat. Acids, Vol. 87, No. 4-5, pp. 135-141, Oct. 2012, doi: 10.1016/J.PLEFA.2012.08.004.

[18] F. P. Casuga, A. L. Castillo, and M. J. A. T. Corpuz, "GC-MS analysis of bioactive compounds present in different extracts of an endemic plant Broussonetia luzonica (Blanco) (Moraceae) leaves," Asian Pac. J. Trop. Biomed., Vol. 6, No. 11, pp. 957961, Nov. 2016, doi: 10.1016/J.APJTB.2016.08.015.

[19] M. N. Asghar, J. Akhtar, M. Shafiq, I. Nadeem, M. Ashfaq, and S. Shahid, "GC-MS and antioxidant capacity analyses of cowpea seeds oils," Nutr. Food Sci., Vol. 43, No. 2, pp. 116126, 2013, doi: 10.1108/00346651311313283.

[20] D. Rath, S. K. Panigrahi, D. M. Kar, and L. Maharana, "Identification of bioactive constituents from different fractions of stems of Cuscuta reflexa Roxb. using GC-MS," Nat. Prod. Res., Vol. 32, No. 16, pp. 1977-1981, 2018, doi: 10.1080/14786419.2017.1356837.

[21] K. Liu, P. G. Rossi, B. Ferrari, L. Berti, J. Casanova, and F. Tomi, "Composition, irregular terpenoids, chemical variability and antibacterial activity of the essential oil from Santolina corsica Jordan et Fourr," Phytochemistry, Vol. 68, No. 12, pp. 1698-1705, Jun. 2007, doi: 10.1016/J.PHYTOCHEM.2007.04.027.

[22] D. C. Obasi and V. N. Ogugua, "GC-MS analysis, pH and antioxidant effect of Ruzu herbal bitters on alloxan-induced diabetic rats," Biochem. Biophys. Reports, Vol. 27, p. 101057, Sep. 2021, doi: 10.1016/J.BBREP.2021.101057.

[23] N. Kalogeropoulos, A. Chiou, V. Pyriochou, A. Peristeraki, and V. T. Karathanos, "Bioactive phytochemicals in industrial tomatoes and their processing byproducts," LWT - Food Sci. Technol., Vol. 49, No. 2, pp. 213-216, Dec. 2012, doi:
10.1016/J.LWT.2011.12.036

[24] R. Kawuri and I. B. G. Darmayasa, "Bioactive compound of Streptomyces capoamus as biocontrol of Bacterial Wilt Disease on Banana Plant," in IOP Conference Series: Earth and Environmental Science, 2019, Vol. 347, No. 1, pp. 1-9, doi: 10.1088/1755-1315/347/1/012054.

[25] A. O. Nogueira, Y. I. S. Oliveira, B. L. Adjafre, M. E. A. de Moraes, and G. F. Aragão, "Pharmacological effects of the isomeric mixture of alpha and beta amyrin from Protium heptaphyllum: a literature review," Fundamental and Clinical Pharmacology, Vol. 33, No. 1. pp. 4-12, 2019, doi: $10.1111 /$ fcp. 12402 .

[26] G. Eswaraiah, K. A. Peele, S. Krupanidhi, R. B. Kumar, and T. C. Venkateswarulu, "Identification of bioactive compounds in leaf extract of Avicennia alba by GC-MS analysis and evaluation of its in-vitro anti-cancer potential against MCF7 and HeLa cell lines," J. King Saud Univ. - Sci., Vol. 32, No. 1, pp. 740-744, Jan. 2020, doi: 10.1016/J.JKSUS.2018.12.010.

[27] S. J. Uddin, D. Grice, and E. Tiralongo, "Pharmaceutical Biology Evaluation of cytotoxic activity of patriscabratine, tetracosane and various flavonoids isolated from the Bangladeshi medicinal plant Acrostichum aureum," Pharm. Biol., Vol. 50, No. 10, pp. 1276-1280, 2012, doi: 10.3109/13880209.2012.673628.

[28] M. Ye et al., "Leonurusoleanolides E-J, minor spirocyclic triterpenoids from leonurus japonicus fruits," J. Nat. Prod., Vol. 77, No. 1, pp. 178-182, 2014, doi: 10.1021/np400838a.

[29] C. Wang et al., "Investigation on pharmacokinetics, tissue distribution and excretion of 1-triacontanol in rats by gas chromatography-tandem mass spectrometry (GC-MS/MS)," Xenobiotica, Vol. 45, No. 1, pp. 71-78, 2015, doi: 10.3109/00498254.2014.943334.

[30] K. Shunmugapriya, P. Vennila, S. Thirukkumar, and M. Ilamaran, "Identification of bioactive components in Moringa oleifera fruit by GC-MS," J. Pharmacogn. Phytochem., Vol. 6, No. 3, pp. 748-751, 2017.

[31] A. El Kabouss, Z. Charrouf, M. Faid, F. X. Garneau, and G. Collin, "Chemical composition and antimicrobial activity of the leaf essential oil of Argania spinosa L. Skeels," J. Essent. Oil Res., Vol. 14, No. 2, pp. 147-149, 2002, doi: 10.1080/10412905.2002.9699801.

[32] L. Zhang et al., "Simultaneous determination of tocopherols, carotenoids and phytosterols in edible vegetable oil by ultrasound-assisted saponification, LLE and LC-MS/MS," Food Chem., Vol. 289, pp. 313-319, Aug. 2019, doi: 10.1016/J.FOODCHEM.2019.03.067.

[33] P. Molyneux, "The Use of the Stable Free Radical Diphenylpicryl-hydrazyl (DPPH) for Estimating Antioxidant Activity," Songklanakarin J. Sci. Technol., Vol. 26, No. 2, pp. 211-219, 2004, doi: 10.1287/isre.6.2.144.

[34] M. Y. Shon, T. H. Kim, and N. J. Sung, "Antioxidants and free radical scavenging activity of Phellinus baumii (Phellinus of Hymenochaetaceae) extracts," Food Chem., Vol. 82, No. 4, pp. 593-597, 2003, doi: 10.1016/S0308-8146(03)00015-3. 